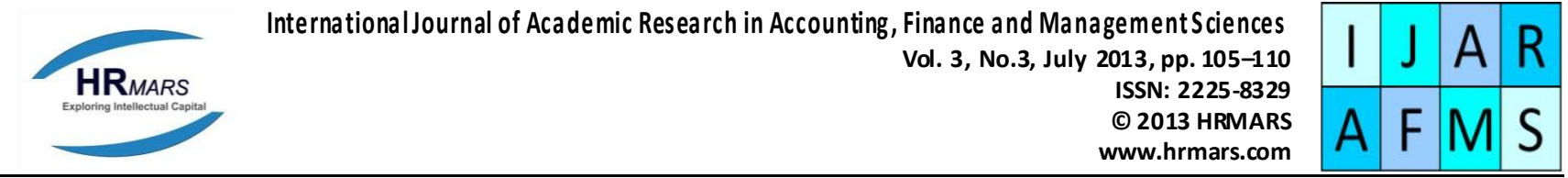

\title{
Information Asymmetry and Financing Decisions: Evidence from Iran Stock Exchange
}

\author{
Mehdi Elhaei SAHAR ${ }^{1}$ \\ Seyed Ali VAEZ ${ }^{2}$ \\ ${ }^{1}$ Department of Accounting, Islamic Azad University, Sousangerd Branch, Sousangerd, Iran, \\ ${ }^{1}$ E-mail: m.elhaee@siau.ac.ir \\ ${ }^{2}$ Department of Accounting, Shahid Chamran University, Ahwaz, Iran

\begin{abstract}
This study aims to investigate the relations of information asymmetry and financing decisions in Tehran Stock Exchange (TSE) during 2009 to 2011. Our statistical simple consist 170 firms and stepwise regression method has been used. We found that the relationship between information asymmetry and stock issuing is negative. Other results refer to positive relation between financing deficit and stock issuing.

Key words Information Asymmetry, Pecking Order Theory, Capital Structure Tehran Stock Exchange (TSE)
\end{abstract}

DOI : 10.6007/IJARAFMS/v3-i3/41

URL: http://dx.doi.org/10.6007/IJARAFMS/v3-i3/41

\section{Introduction}

In the Static Tradeoff Model (Myers, 1977), two frictions, the agency costs of financial distress and the tax-deductibility of debt finance, generate an optimal capital structure. An alternative model (Myers and Majluf, 1984) emphasizes frictions due to asymmetric information between managers and outside investors. In this Pecking Order Model, a financial hierarchy descends from internal funds, to debt, to external equity. The central friction in the Pecking Order Model of capital structure is the asymmetric information between managers and less-informed outside investors. Myers and Majluf (1984) show how this asymmetry leads firms to prefer internal funds to external funds. When the former are exhausted and there exists a deficit in funds, firms will prefer safer debt to riskier equity. Thus, there exists a financial hierarchy descending from internal funds, to debt, to external equity. Funds are raised through equity issues only after the capacity to issue debt has been exhausted. Frank and Goyal (2003) question the hypothesis that the pecking order theory offers a good approximation for firms' financing choices. They document that net equity issuances track the financing deficit more closely than net debt issuances, a result contrary to the static pecking order theory. Chirinko and Singha (2000) argue that Shyam-Sunder and Myers's (1999) results suffer from econometric problems related to the power of their tests. As pointed out by Myers and Majluf (1984), another main implication of the pecking order theory is that firms will issue equity and build up cash reserves when information asymmetry is temporarily low. They claim that if managers know more than the market, firms should avoid situations in which valuable investment projects have to be financed by equity issuances. Holding financial slack solves the problem, and one way to build up cash reserves is to issue equity when there is little asymmetric information. The time-varying adverse selection explanation of firms' financing choices is the dynamic analog of the static pecking

Order theory, which suggests that firms tend to iss ue equity when stock prices are high and if a high stock price coincides with low adverse selection. Assuming that the degree of information asymmetry is timevarying, the magnitude of adverse selection costs is to some extent under the firm's control (Korajczyk et al. 1992). 
Lemmon and Zender (2004) counter this challenge by controlling for the value of maintaining financial slack for future investment and to avoid financial distress. Yet, Leary and Roberts (2004) incorporate financial slack in their explicit analysis of the hierarchy of financing policies generated by the pecking order theory and do not find support for it. In short, the existing evidence on the pecking order is mixed. In sharp contrast to those studies, in this artide we do not seek to test the predictions of the pecking order theory. Instead, we evaluate its core assumption i.e., information asymmetry as the determinant of capital structure decisions. As Fama and French (2005) observe, ultimately the pecking order theory posits that information asymmetry is an important (or perhaps even the sole) determinant of firms' capital structure. However, no test has ever been performed to ascertain the empirical viability of that basic assumption of the theory. In other words, we still do not know whether information asymmetry drives firms' capital structure decisions. That is the specific question we address in this research. In particular, we study the conformity of those decisions to the pecking order theory for different degrees of information asymmetry. If the theory correctly describes the funding process of corporations, we expect this conformity to be greater the higher is the estimated intensity of perceived information asymmetry between managers and all other market participants.

Bharath et al. (2009) Using a novel information asymmetry index based on measures of adverse selection developed by the market microstructure literature, They test whether information asymmetry is an important determinant of capital structure decisions, as suggested by the pecking order theory. Their index relies exclusively on measures of the market's assessment of adverse selection risk rather than on ex ante firm characteristics. They find that information asymmetry does affect the capital structure decisions of U.S. firms over the sample period 1973-2002. Their findings are robust to controlling for conventional leverage factors (size, tangibility, $Q$ ratio, and profitability), the sources of firms' financing needs, and such firm attributes as stock return volatility, stock turnover, and intensity of insider trading. For example, they estimate that on average, for every dollar of financing deficit to cover, firms in the highest adverse selection deciles issue 30 cents of debt more than firms in the lowest deciles. Overall, this evidence explains why the pecking order theory is only partially successful in explaining all of firms' capital structure decisions. It also suggests that the theory finds support when its basic assumptions hold in the data, as should reasonably be expected of any theory. Other study that accomplished by Bessler et al. (2011) conduct tests of the pecking order theory using an international sample with more than 6000 firms over the period from 1995 to 2005. The high correlation between net equity issuances and the financing deficit discredits the static pecking order theory. Rather than analyzing the predictions of the theory, they test its core assumption that information asymmetry is an important determinant of capital structure decisions. Their empirical results support the dynamic pecking order theory and its two testable implications. First, the probability of issuing equity increases with less pronounced firm-level information asymmetry. Second, firms exploit windows of opportunity by making relatively larger equity issuances and build up cash reserves (slack) after declines in firm-level information asymmetry. Firms from common law countries use parts of their proceeds from an equity issuance to redeem debt and to rebalance their capital structure. These findings are consistent with a time-varying adverse selection explanation of firms' financing decisions. As we point out previous to this, the goal of study testing pecking order theory in Tehran Stock Exchange (TSE).

The remainder of this paper is organized as follows. Section 2 presents methodology of study. Section 3 shows our empirical results. Finally, Section 4 concludes about research findings.

\section{Methodology of research}

In this study the Statistical population is all listed firms which are in Tehran Stock Exchange during the period of 2009 to 2011 (three-year period).

We selected a sample contain 170 firms according to some conditions such as:

1. End of firm fiscal year should be at end of hegira year which matches with March.

2. The firm should not change on fiscal during years of desire (2009 to 2011).

3. This firm is active during research and its shares are traded and book value of equity is not negative in any year.

4. The financial information required for conducting the research in the period of 2009 to 2011 which is fully provided and by the firm that should not be a financial or investment one and be profitable. 
With due attention to this conditions at end we elect 170 firms as statistical sample. Just as we point before, aim of this paper is testing the pecking order theory in (TSE) during 2009 to 2011 by 170 firms. Therefore, for this aim, we used two models according Bessler et al. (2011) and by look at some data limitation we adjusted the models. They examine the hypothesis that firms exploit windows of opportunity. Firms that face more severe information asymmetry issue equity less frequently. These firms anticipate being constrained from issuing equity in the future, and hence they issue in larger amounts when the general market conditions are more favorable. They quote by Chang and Dasgupta (2009), both dynamic adverse selection considerations and market timing behavior imply that stock price run-ups are positively related to the size of equity issuances. However, based on Lucas and McDonald's (1990) notion that the gradual resolution of information asymmetry triggered the price run-up, the time varying adverse selection explanation offers an additional testable implication. Low information asymmetry not only increases the probability of an equity issuance, but firms should also issue a relatively larger volume of equity when information asymmetry is temporarily low. In order to test these hypotheses, we estimate the following model:

$$
\text { Esize }_{t}=\alpha+\beta_{1} D E F_{i t}+\beta_{2} D{ }^{S P} P_{i t}+\beta_{3} \text { TANG }_{i t}+\beta_{4} \text { YOUNG }_{i t}+\beta_{5} \text { SIZE }_{i t}+\varepsilon_{i t}
$$

Where:

Esize : Esize is defined as net equity issued divided by total assets.

$D E F: D E F$ is the conventional definition of the financing deficit (Frank and Goyal 2003);

$D E F=\mathbf{\Delta} D+\mathbf{\Delta} E$

$\Delta D$ : Changes in issuance of debt.

$\Delta E$ : Changes in issuance of equity.

$D I S P$ : That is proxy of information asymmetry that computed as follows:

$D I S P=1+\frac{E P S-\text { For }- \text { Dev }}{\operatorname{Re}-\text { EPS }}$

$E P S-F o r-D e v$ : is earning per share estimated by analysts.

Re - EPS : That is real earning per share.

$T A N G$ : Book value of tangible asset.

$Y O U N G$ : That is dummy variable, which equals 1 for firms that have been in operation for less than 10 years, and 0 otherwise.

$S I Z E$ : Firm size is the natural logarithm of total assets of the firm.

According Bessler et al. (2011) also we test the hypothesis of the dynamic pecking order theory that firms choose to issue a larger volume of equity when adverse selection costs are temporarily low in order to build up or preserve a stockpile of internal funds. This notion is consistent with Viswanath's (1993) model, where managers issue equity when information asymmetry is low and buffer cash to ensure financing for future investment projects. If the potential loss of future projects (because of unacceptable dilution resulting from issuing risky securities to finance them) becomes excessive, the manager may deviate from the static pecking order and choose to issue a risky security to finance a current investment, even though he has the option to use cash or issue a less risky security (such as debt). Therefore, a more complete hypothesis in the context of the dynamic pecking order theory is that firms choose to issue a larger volume of equity when adverse selection costs are low in order to build up or preserve financial slack for positive net present value projects that will emerge in future periods. Specifically, using the set of variables that are commonly used in models to estimate target cash holdings (Opler et al. 1999; Drobetz and Gru“ninger 2007; Drobetz et al . 2010), we estimate the following model: 


$$
\Delta \mathrm{CASH}_{\mathrm{it}}=\alpha+\beta_{1} \mathrm{DISP}_{\mathrm{it}}+\beta_{2} I \mathrm{D}_{\mathrm{it}}+\beta_{3} \mathrm{TANG}_{\mathrm{it}}+\beta_{4} \text { YOUNG }_{\mathrm{it}}+\beta_{5} \mathrm{SIZE}_{\mathrm{it}}+\beta_{6} \mathrm{DIV}_{\mathrm{it}}+\beta_{7} \mathrm{LEV}_{\mathrm{it}}+\varepsilon_{\mathrm{it}}
$$

Where:

$\triangle C A S H$ : That is defined as the change in cash and marketable securities divided by total assets.

ID: ID is an issuing dummy variable that takes the value of 1 if the firm issues equity in a given year and 0 otherwise.

DIV: DIV is a dummy variable that takes the value of 1 if the firm is a dividend-payer in a given year and 0 otherwise.

LEV : LEV is leverage, measured as a firm's total debt (short- and long-term debt) divided by total assets.

\section{Test of models Significant}

\subsection{Test of first model significant}

In this section, we will check the effect of assumed variable on the firm value. Basic statistical assumption states that any one of the independent variables does not influence to the dependent variable changes. In contrast, the alternative statistical hypotheses are expressed, which there is at least an explanatory variable that effects the dependent variables changes. In other words, for the first model:

$$
\begin{aligned}
& \mathrm{H}_{0}=\mathrm{a}_{1}=\mathrm{a}_{2}=\mathrm{a}_{3} \ldots=\mathrm{a}_{24}=0 \\
& \mathrm{H}_{1}=\mathrm{a}_{\mathrm{i}} \neq 0 \text { at least for an } \mathrm{i}
\end{aligned}
$$

According to the perceived values $(F=4 / 323$, Sig=0/006) that the test statistics is located in rejection the $\mathrm{H}_{0}$ region. So, at least there where one variable influencing on firm value, and there is not any reason to reject the entirely the first model significant. Coefficient of determination $\left(R^{2}=0 / 072\right)$ also shows that about $7 / 2$ percent of Esize changes are described by the regression model. Consequently, the first model and the

\begin{tabular}{|c|c|c|c|}
\hline \multicolumn{4}{|c|}{ Dependent variable: Esize } \\
\hline Level of significance & T statistic & Unstandardized Coefficients & Independent variable \\
\hline $0 / 000$ & $6 / 036$ & $0 / 021$ & Constant \\
\hline $0 / 031$ & $-2 / 178$ & $-6 / 713 \mathrm{E}-6$ & DISP \\
\hline $0 / 005$ & $2 / 879$ & $-2 / 840 \mathrm{E}-8$ & DEF \\
\hline $0 / 054$ & $-1 / 941$ & $2 / 411 \mathrm{E}-9$ & Tang \\
\hline$R^{2}=0 / 072$ & \multicolumn{2}{|c|}{ Adjusted $-R^{2}=0 / 056$} & \\
\hline *level of significance & s $\% 10$ & & \\
\hline
\end{tabular}
final results are as follows:

Table 1. The final step (4) for first model

\subsection{Test of second model significant}

In this section, we will check the effect of assumed variable on the firm retum. Basic statistical assumption states that any one of the independent variables does not influence to the dependent variable changes. In contrast, the alternative statistical hypotheses are expressed, which there is at least an explanatory variable that effects the dependent variables changes. In other words, for the second model:

$$
\begin{aligned}
& \mathrm{H}_{0}=\mathrm{a}_{1}=\mathrm{a}_{2}=\mathrm{a}_{3} \ldots=\mathrm{a}_{24}=0 \\
& \mathrm{H}_{1}=\mathrm{a}_{\mathrm{i}} \neq 0 \text { at least for an } \mathrm{i}
\end{aligned}
$$

According to the perceived values $(F=5 / 092, S i g=0 / 007)$ that the test statistics is not located in rejection the $\mathrm{H}_{0}$ region. Coefficient of determination $\left(\mathrm{R}^{2}=0 / 057\right)$ also shows that about $5 / 7$ percent of $\triangle C A S H$ changes are described by the regression model. Consequently, the second model and the final results are as follows: 
Table 2. The final step (7) for second model

\begin{tabular}{llll}
\hline Dependent variable: & $\Delta$ CASH & & \\
\hline Level of significance & T statistic & Unstandardized Coefficients & Independent variable \\
$\mathbf{0 / 0 0 2}$ & $3 / 145$ & $0 / 007$ & Constant \\
$\mathbf{0 / 0 0 8}$ & $-2 / 705$ & $-5 / 647 \mathrm{E}-6$ & DISP \\
$\mathbf{0 / 0 7 8}$ & $1 / 774$ & $9 / 556 \mathrm{E}-10$ & Tang \\
& & & \\
$\mathbf{R}^{\mathbf{2}} \mathbf{0} \mathbf{0} \mathbf{0 7 2}$ & Adjusted $-\mathbf{R}^{\mathbf{2}}=\mathbf{0} / \mathbf{0 5 6}$ & $\mathbf{F}=\mathbf{4 / 3 2 3}$ \\
\hline *level of significance is $\% 10$ & & \\
\hline
\end{tabular}

\section{Conclusions}

Our investigations indicate that the information asymmetry is important factor on equity issuance in Tehran Stock Exchange during 2009 to 2011. In other word, when information asymmetry is low, firm intend to issue most equity. This finding is confirmed with dynamic pecking order theory in Iran Stock Market. This finding conforms to Bessler et al. (2011).

Other results of study show that there is negative relationship between information as ymmetry and cash resenves. We argue that firms try to decrease asymmetry information to assure all stakeholders that disclosure level is enough and there is not any information split, thereafter, they issue equity and earn cash resources. Also, we found firms when subject to financial deficit, embarking to issue equity. There is positive relationship between tangible asset and equity issuance. In other word, firms when earn cash resources through issue equity, they invest in tangible assets. But this finding statistically is weak.

\section{References}

1. Akerlof, G., Spence, M. and Stiglitz J. (1970). Market with asymmetric information. http://www.Nobelprize.org/economist.

2. Ben Ali, Chiraz, (2009). "Disclosure Quality and Corporate Governance in a Context of Minority Expropriation". Available at SSRN: http:/ /ssm. com/ abstract= 1406149.

3. Berkovitch E., and E.H. Kim (1990), "Financial Contracting and Leverage Induced Over-and-UnderInvestment Incentives", Journal of Finance, 45 (3).

4. Bradley M., G.A. Jarrell, and E.H. Kim (1984), "On the Existence of an Optimal Capital Structure: Theory and Evidence", Journal of Finance, 39 (3).

5. Brennan M.J., and E.S. Schwartz (1984), "Optimal Financial Policy and Firm valuation", Journal of Finance, 39 (3).

6. Brounen D., A. de Jong and K. Koedijk (2006), "Capital Structure Policies in Europe: Survey Evidence", Journal of Banking \& Finance, 30 (5).

7. Butters J.K. (1949), "Federal Income Taxation and Extemal vs. Internal Financing", Journal of Finance, 4 (3).

8. Cadsby C.B., M.Z. Frank, and V. Maksimovic(1990), "Pooling, Separating, and Semi Separating Equilibria in Financial Markets: Some Experimental Evidence", Review of Financial Studies, 3 (3).

9. Cai, Jie and Liu, Yixin and Qian, Yiming (2008), "Information Asymmetry and Corporate Governance", available at: http://ssrn.com.

10. Chirinko, R., and A. Singha (2000), 'Testing Static Trade off against Pecking Order Models of Capital Structure: A Critical Comment', Journal of Financial Economics, 58, 417-27.

11. DeAngelo H., and L. DeAngelo (2006), "Capital Structure, Payout Policy, and Financial Flexibility", Working Paper No. FBE 02-06, Marshall School of Business, University of Southern California. Available at SSRN: http://ssrn.com.

12. Fama E.F., and K.R. French (1998), "Taxes, Financing Decisions, and Firm Value", Journal of Finance, $53(3)$.

13. Fama, E. F., and K. R. French (2005), 'Financing Decisions: Who Issues Stock?', Journal of Financial Economics, 76, 549-82. 
14. Fischer E.O., R. Heinkel, and J. Zechner (1989), "Dynamic Capital Structure Choice: Theory and Tests", Journal of Finance, 44 (1).

15. Frank M.Z., and V.K. Goyal (2005), "Trade-Off and Pecking Order Theories of Debt", Working Paper, Carlson School of Management, University of Minnesota. Available at SSRN: http://ssrn.com/abstract=670543

16. Frydenberg S. (2004), "Theory of Capital Structure - A Review", Working Paper, Department of Business Administration, Sor-Trondelag University College, Trondheim, Norway.

17. Graham J.R. (2003), "Taxes and Corporate Finance: A Review", Review of Financial Studies, 16 (4).

18. Jensen M.C., and W.H. Meckling (1976), "Theory of the Firm: Managerial Behavior, Agency Costs, and Ownership Structure", Journal of Financial Economics, 3 (4).

19. Kane A., A.J. Marcus, and R.L. McDonald (1984), "How big is the Tax Advantage to Debt?" Journal of Finance, 39 (3).

20. Korajczyk, R.A., D. J. Lucas, andR. L.McDonald (1992), 'Equity Issues with Time-Varying Asymmetric Information', Journal of Financial and Quantitative Analysis, 27, 397-417.

21. Kraus A., and R.H. Litzenberger (1973), "A State-Preference Model of Optimal Financial Leverage",Journal of Finance, 28 (4).

22. Leary M.T., and M.R. Roberts (2006), "ThePecking Order, Debt Capacity, and Information Asymmetry", Working Paper, Fuqua School of Business, Duke University. Available at SSRN: http://ssrn.com/abstract=555805.

23. Lemmon, M. L., and J. F. Zender (2009), 'Debt Capacity and Tests of Capital Structure Theories', Journal of Financial and Quantitative Analysis, Cambridge University Press,17 Aug 2010. doi: 10.1017/S0022109010000499.

24. Miller M.H. (1977), "Debt and Taxes", Journal of Finance, 32 (2).

25. Modigliani F., and M.H. Miller (1958), "The Cost of Capital Corporation Finance and the Theory of Investment", American Economic Review, 48 (3).

26. Modigliani F., and M.H. Miller (1963), "Corporate Income Taxes and the Cost of Capital: A Correction", American Economic Review, 53 (?).

27. Myers S.C. (1984), "The Capital Structure Puzzle", Journal of Finance, 39 (3).

28. Myers S.C. G. Constantinides, M. Harris, and R. Stulz (2003), "Financing of Corporations", Handbook of the Economics of Finance (Vol. 1A), Elsevier.

29. Myers S.C., and N.S. Majluf (1984), "Corporate Financing and Investment Decisions When Firms Have Information that Investors Do Not Have", Journal of Financial Economics, 13 (2).

30. Shyam-Sunder, L., and S. C. Myers (1999), 'Testing Static Trade off against Pecking Order Models of Capital Structure', Journal of Financial Economics, 51, 219-44. 